\title{
Inhibition of Net Sodium Transport in Single Sweat Glands by Sweat of Patients with Gystic Fibrosis of the Pancreas
}

\author{
D. KaISeR ${ }^{[31]}$, E. Drack, and E. Rossi \\ Department of Pediatrics, University of Bern, Bern, Switzerland
}

\begin{abstract}
Extract
By micropuncture techniques and sweat collection under mineral oil, sweat from patients with cystic fibrosis of the pancreas (sweat-GFP) and from normal controls (sweat$\mathrm{N}$ ) was perfused for 7 min into ducts of single sweat glands in fingers of normal subjects. After pilocarpine stimulation, and after discarding the samples collected during the first $5 \mathrm{~min}$, sweat of the infused gland was collected over a period of 40-80 min.

The results were as follows: at all flow rates and over the whole period of time, a significant increase was observed in the sodium concentration of the sweat. The mean sodium concentrations were $62.0 \pm 18.0 \mathrm{sD} \mathrm{mEq} /$ liter after perfusion with sweat-CFP and $20.0 \pm 7.0 \mathrm{sD} \mathrm{mEq} /$ liter after infusion of sweat-N (Fig. 2). The increase in potassium concentration seen after infusion of sweat-CFP (mean $19.9 \pm 5.0 \mathrm{sD} \mathrm{mEq} / \mathrm{liter}$ ) compared with that seen after infusion of sweat-N (mean $9.0 \pm 5.5 \mathrm{sD} \mathrm{mEq} /$ liter) was compatible with that observed in sweat-CFP (Fig. 3). In contrast to retrograde infusion, subcutaneous infiltration of normal glands with sweat-CFP had no effect on either sodium or potassium concentration.
\end{abstract}

\section{Speculation}

The results clearly prove the humoral transducibility of the electrolyte defect reported in CFP and make the existence of a net sodium transport-inhibiting factor in sweatCFP even more probable. We speculate from these data that the factor might be a derivative of the sweat glands themselves rather than a substance present in blood, or interstitial fluid, or both.

\section{Introduction}

The presence of high concentrations of sodium in the sweat of patients with cystic fibrosis of the pancreas (sweat-CFP) is widely accepted by all investigators and is one of the most important manifestations of the genetic defect $[3,4]$. The underlying basic defect, however, remains poorly understood. Results published by Slegers [22] and confirmed by Emrich et al. [7] prove that a reduced net rate of sodium reabsorption occurs in the sweat gland duct. Recently, Mangos and McSherry $[17,18]$ demonstrated humoral transducibility of this sodium transport defect: mixed mouth saliva and sweat-CFP were infused into the duct system of a rat parotid gland and caused a marked increase in the sodium concentration of the saliva produced by the parotid thereafter. It was suggested that a "factor" might be responsible for this electrolyte defect which interferes directly with the membrane structures of the reabsorbing epithelial cells. 
No attempt to prove the action of this factor on sweat glands of normal humans has been reported. This experiment, transferring the effect from morbid to normal sweat glands, would be critical since the sweat glands are the only exocrine serous glands with a clearly established defect in net sodium transport [4]. We chose the singie sweat gland as the functional unit of sweat performance for our studies and, using micropuncture techniques, succeeded in perfusing the duct of sweat glands from control subjects with sweat-CFP. The sweat produced by the glands thereafter showed a significant increase in sodium concentration at all flow rates and over long periods of time. In contrast to retrograde perfusion, subcutaneous infiltration of the glands had no effect on the sodium excreted. These results clearly demonstrate the humoral transducibility of the net sodium transport defect.

\section{Materials and Methods}

Fourteen children with CFP, between 3 and 8 years of age, and a control group of 11 healthy children of the same ages, were used as sweat donors. Neither group of subjects was receiving drugs known to affect sodium transport. None of the sweat donors was used twice. The only therapy used for children with CFP was inhalation 1-2 times/24 hr of 150-300 mg N-acetyl-Lcysteine [25]. The collected sweat was infused into the ducts of single sweat glands in the fingers of 11 healthy adults. Each control subject was used for one experiment with sweat-CFP and one experiment with sweat$\mathrm{N}$. Three adult controls were used twice for perfusion with sweat-CFP.

Sweat-CFP and sweat-N were collected under mineral oil from the forearm after pilocarpine stimulation. According to the techniques of Emrich et al. [7], the sweat of 150-200 glands was sucked up in PVC capillaries and total volume was determined; it was stored on a siliconized microscope slide under mineral oil. The sodium concentration of each sample of sweat- $\mathrm{N}$ was adjusted to the level of the corresponding sample of sweat-CFP by adding the required amount of $\mathrm{l} \mathrm{N} \mathrm{NaCl}$.

To puncture the sweat gland the subject's hand was kept under oil in a "hand shaped" plaster cast. Light transmitted by fiber optics [26] and a stereomicroscope $(40 \times)$ [27] showed the stretched final parts of the sweat gland ducts near the nail bed. A micromanipulator [28] was used to puncture the orifice of the gland with a siliconized microglass capillary (outer diameter $20 \mu$ ) with sharpened tip, containing about 50-200 nl of sweat. The capillary was pushed forward in the duct for another $100-150 \mu$. With compressed air (2 atm on bottle outlet) the test solution in the capillary was continually infused into the gland duct. When the capillary was well situated in the lumen, the injected fluid reached the lower part of the duct system, placing the cells of the deeper duct parts in contact with the test solution. This was demonstrated in experiments with Lissamin green, in which migration of the dye even down to the coil was achieved. Moreover, our procedure is in accordance with the results of Schulz et al. [20, 21], who filled the sweat gland duct with colored ricinus oil and observed that the oil had reached the coil.

The sweat gland was infused over a period of $7 \mathrm{~min}$. After withdrawal of the capillary from the gland a few microliters of $2 \%$ pilocarpine were injected intracutaneously into the surrounding tissue with another sharpened glass capillary. The glands started sweating immediately. The first 5-min sample was discarded. Sweat produced subsequently was collected under paraffin oil in small siliconized glass capillaries with a constant inner diameter between 30 and $50 \mu$. The exact length of the oil-blocked sweat column and the inner diameter of the capillary were determined under phase contrast microscopy. From these data the volume and flow rate were calculated. Intracutaneous infiltration with sweat-CFP was done by use of conventional intradermal needles and tuberculin syringes. Determination of sodium and potassium concentration was done in an ultrasensitive flame photometer that permitted simultaneous measurement of both ions in single samples of sweat as small as $0.25 \mathrm{nl}\left(0.25 \cdot 10^{-6}\right.$ $\mathrm{ml}$ ) or $0.5 \cdot 10^{-13} \mathrm{Eq} \mathrm{Na}$ and $10^{-13} \mathrm{Eq} \mathrm{K}$ [24]. All values were obtained from double measurements expressed in milliequivalents per liter and plotted as a function of flow rate (nanoliters per minute).

\section{Results}

The course of a typical experiment on two single glands is illustrated in Figure 1. Flow rates of glands I and $I I$ did not differ significantly from each other (period $A$ ). Concentrations for sodium and potassium were both in the normal low range. During period $B$, gland $I$ was perfused for $7 \mathrm{~min}$ with sweat-CFP and gland II was perfused for the same period of time with sodium-enriched sweat from a control subject. A moderate decrease of flow rate was observed in both glands thereafter. The gland perfused with sweat-CFP, however, produced a sodium- and potassium-rich sweat 
over a 30-min period whereas in the control gland no significant change was observed.

Figure 2 shows the results of 14 experiments per-

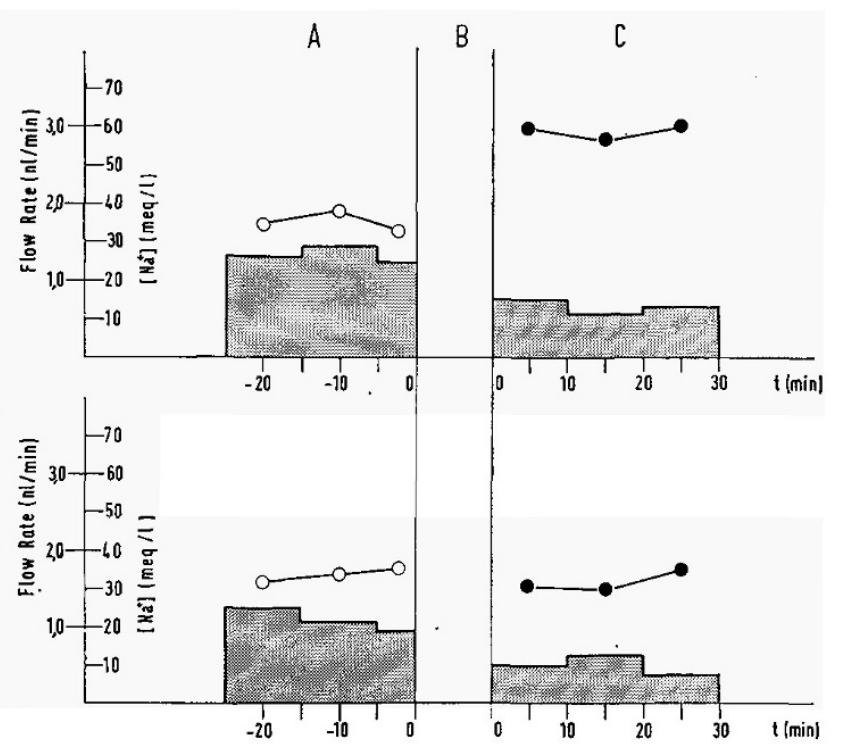

Fig. 1. Infusion of two single sweat glands with sweat from patients with CFP (above, gland $I$ ) and sodium-rich sweat from normal control subjects (below, gland II). A: Preinfusion period. $B$ : Infusion period. $C$ : Postinfusion period. $\bigcirc$ : Sodium concentrations before infusion. $\bullet$ : Sodium concentrations after infusion. Grey areas: Flow rate. formed in the same way with sweat-CFP and from 11 control experiments. Each circle represents the result from one perfusion experiment on a different sweat gland with sweat from a different donor. In some cases subsequent measurements at different flow rates were possible. This explains why the number of measurements exceeded the number of experiments (compare Figs. 2 and 3). At all flow rates and over the entire period of time a markedly higher sodium concentration in the sweat was observed after perfusion with sweat-CFP (mean $62.0 \pm 18.0 \mathrm{sD} \mathrm{mEq} /$ liter, $N=31$, dark circles). In the control experiments with "sodium-rich" sweat- $\mathrm{N}$ the sodium concentration amounted to $20.0 \pm 7.0 \mathrm{sD} \mathrm{mEq} /$ liter (open circles).

In Figure 3 the potassium concentrations after infusions of sweat-CFP (dark circles) and sweat-N (open circles) are plotted as a function of flow rate. Following perfusion of sweat-CFP the potassium concentration excreted was significantly higher than that seen after perfusion of sweat-N (open circles).

In another series of experiments the influence of intracutaneous sweat-GFP on sweat performance was investigated. Table I shows that in 24 control experiments, despite a wide variation in flow rate between 0.2 and $14.6 \mathrm{nl} / \mathrm{min} /$ gland, the mean sodium concentration remained consistently low at $37.5 \pm 12.9 \mathrm{sD} \mathrm{mEq} /$

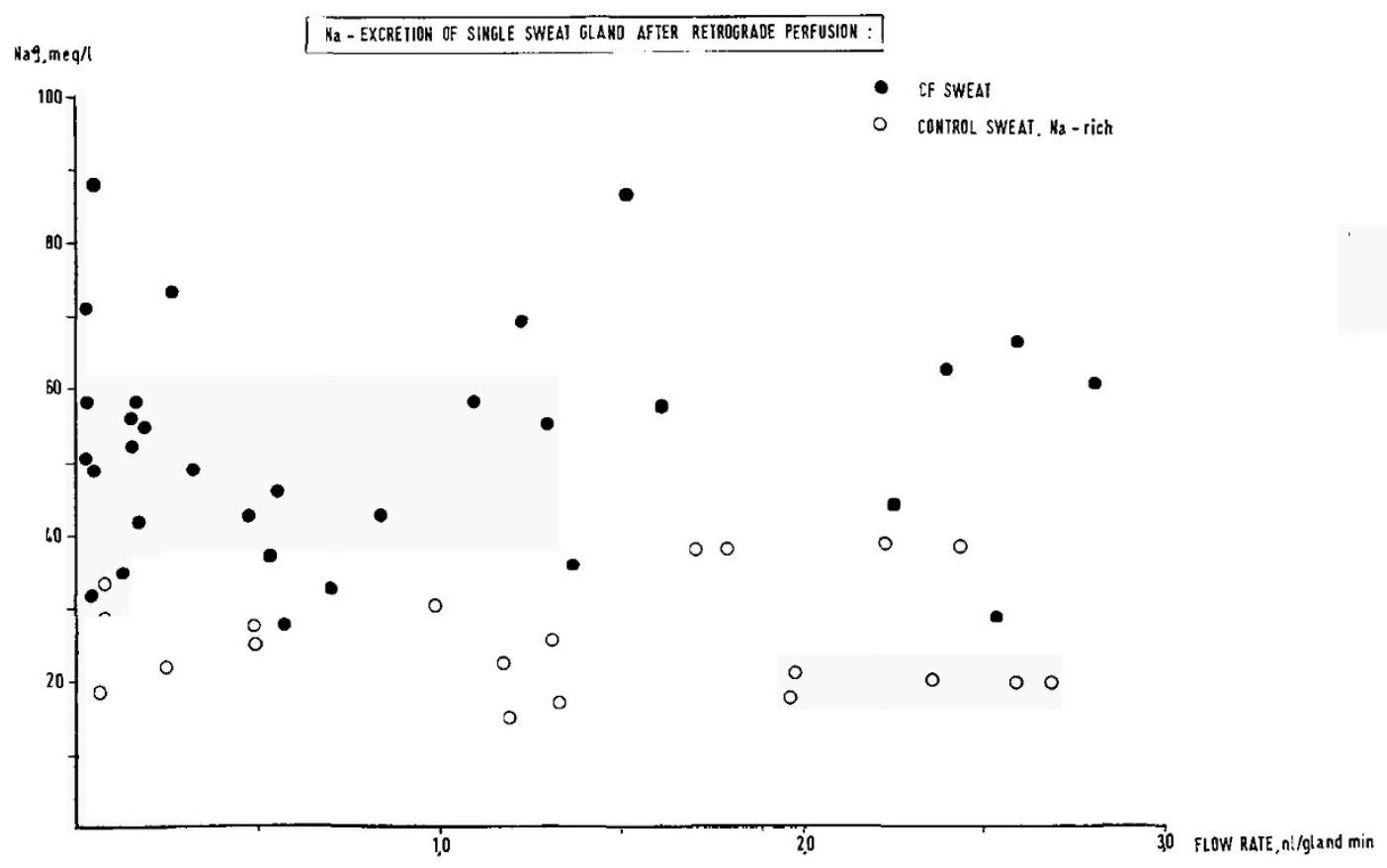

Fig. 2. Sodium concentrations in sweat of single sweat glands of normal controls, plotted as a function of flow rate. : Sodium concentration after infusion with sweat from patients with CFP. $O$ : Sodium concentration after infusion with sodium-rich sweat from control subjects. 


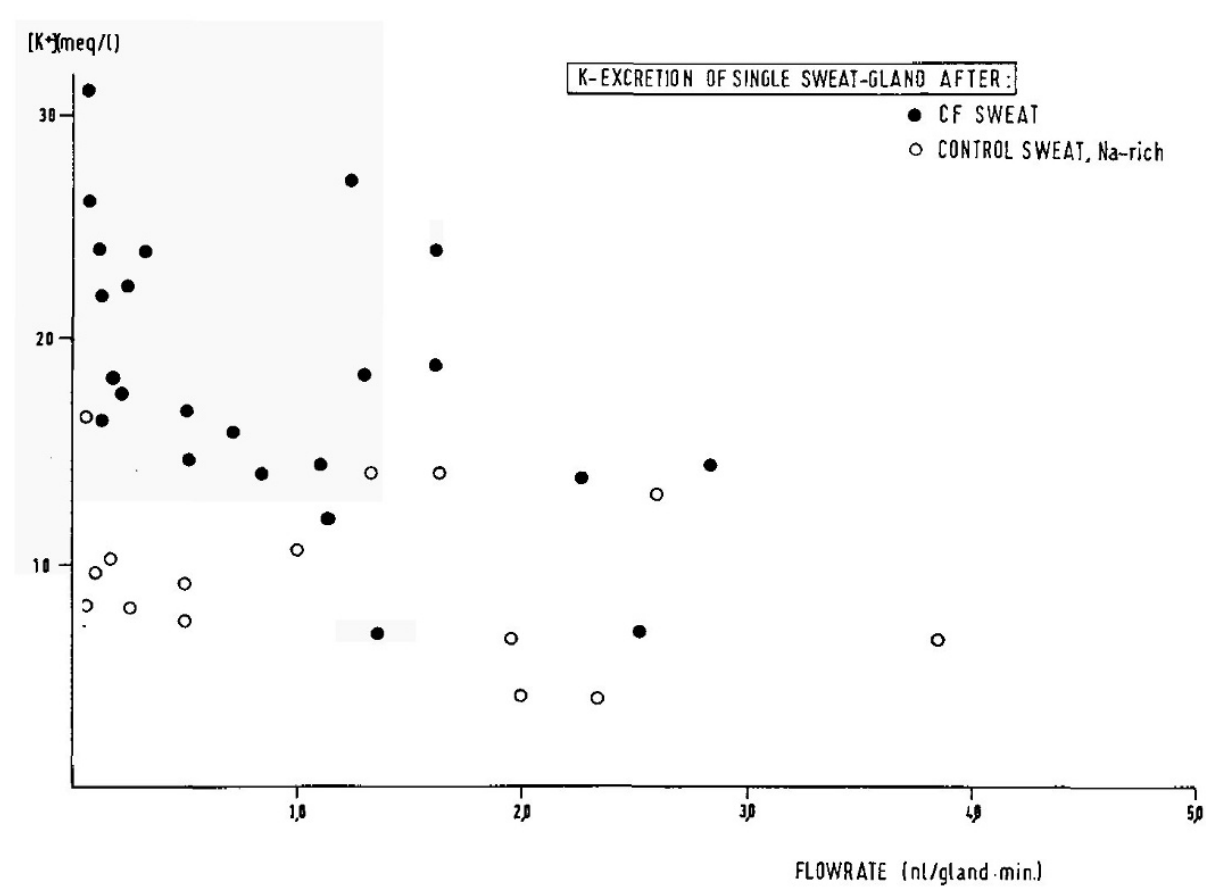

Fig. 3. Potassium concentrations in sweat of single sweat glands of normal controls, plotted as a function of flow rate. : Potassium concentration after infusion with sweat from patients with CFP. O: Potassium concentration after infusion with sodium-rich sweat from control subjects.

Table 1 . Concentrations of $\mathrm{Na}^{+}$and $\mathrm{K}^{+}$and flow rate in the final sweat of single sweat glands

\begin{tabular}{|c|c|c|c|c|c|}
\hline \multicolumn{3}{|c|}{ Controls $^{1}(N=24)$} & \multicolumn{3}{|c|}{ Sweat infiltration ${ }^{2}(N=24)$} \\
\hline$\underset{\mathrm{mEq} / \mathrm{liter}}{\mathrm{Na}}$ & $\underset{\mathrm{mEq} / \mathrm{liter}}{\mathrm{K}}$ & $\begin{array}{l}\text { Flow } \\
\text { rate, } \\
1 / \mathrm{min}\end{array}$ & $\underset{\mathrm{mEq} / \mathrm{liter}}{\mathrm{Na}}$ & $\underset{\mathrm{mE} q / \text { liter }}{\mathrm{K}}$ & $\begin{array}{l}\text { Flow } \\
\text { rate, } \\
\mathrm{l} / \mathrm{min}\end{array}$ \\
\hline 13.0 & 10.0 & 0.2 & 47.0 & 6.5 & 0.3 \\
\hline 25.0 & 16.0 & 0.2 & 50.0 & 7.0 & 0.4 \\
\hline 58.0 & 13.0 & 0.3 & 36.0 & 6.5 & 0.4 \\
\hline 43.0 & 11.0 & 0.6 & 15.0 & 7.0 & 0.5 \\
\hline 47.0 & 10.0 & 0.7 & 19.0 & 6.0 & 0.5 \\
\hline 33.0 & 7.0 & 0.8 & 52.0 & 6.5 & 0.5 \\
\hline 36.0 & 7.5 & 0.9 & 31.0 & 10.0 & 0.6 \\
\hline 57.0 & 6.0 & 0.9 & 52.0 & 7.5 & 0.6 \\
\hline 58.0 & 7.0 & 0.9 & 36.0 & 8.5 & 0.9 \\
\hline 23.0 & 5.0 & 1.1 & 36.0 & 7.0 & 0.8 \\
\hline 28.0 & 5.5 & 1.2 & 31.0 & 9.0 & 0.8 \\
\hline 45.0 & 7.5 & 1.2 & 31.0 & 6.5 & 0.9 \\
\hline 46.0 & 25.0 & 1.3 & 23.0 & 11.5 & 0.9 \\
\hline 26.0 & 6.0 & 1.3 & 20.0 & 7.0 & 0.9 \\
\hline 25.0 & 23.0 & 1.7 & 23.0 & 6.0 & 1.0 \\
\hline 32.0 & 18.0 & 2.7 & 23.0 & 6.0 & 1.1 \\
\hline 19.0 & 15.0 & 3.1 & 26.0 & 6.0 & 1.1 \\
\hline 42.0 & 7.5 & 4.3 & 15.0 & 12.0 & 1.2 \\
\hline 24.0 & 11.0 & 4.7 & 20.0 & 7.0 & 1.4 \\
\hline 52.0 & 9.5 & 5.5 & 24.0 & 19.0 & 2.2 \\
\hline 47.0 & 6.0 & 8.1 & 35.0 & 6.0 & 2.5 \\
\hline 31.0 & 12.5 & 8.9 & 51.0 & 7.5 & 5.4 \\
\hline 34.0 & 6.0 & 13.2 & 42.0 & 6.0 & 5.5 \\
\hline 40.0 & 5.0 & 14.6 & 48.0 & 6.0 & 6.2 \\
\hline $37.5 \pm 12.9^{3}$ & $10.3 \pm 5.5$ & & $33.6 \pm 12.7$ & $7.8 \neq 2.9$ & \\
\hline
\end{tabular}

liter. No relation between the sodium concentration and the flow rate, especially no approach to isotonicity with increasing flow rates, could be observed. Similarly, after infiltration of the surrounding skin area with sweat-CFP sodium concentrations remained at low values for all flow rates (mean $33.6 \pm 12.7 \mathrm{sD} \mathrm{mEq} /$ liter); thus, sweat-CFP injected intracutaneously appeared to have no effect on sodium or potassium excretion. Mean potassium concentrations were $10.3 \pm 5.5 \mathrm{sD} \mathrm{mEq} /$ liter in sweat-N and $7.8 \pm 2.9 \mathrm{sD} \mathrm{mEq} /$ liter in sweat-CFP.

\section{Discussion}

Our results prove that the electrolyte transport defect present in sweat glands of children with cystic fibrosis of the pancreas (CFP) can be transferred humorally to normally functioning sweat glands of healthy subjects. When this sweat from children with CFP was infused into the duct of a normal sweat gland over a period of several minutes, a sodium- and potassium-rich sweat was produced over a long period of time and at all flow rates thereafter. Control sweat from normal donors with a sodium concentration elevated to levels found in sweat of patients with CFP, however, had no effect; the sodium and potassium concentrations of this sweat remained in a normal low range. Further 
comparison of the results leads to the conclusion that the increased sodium concentration after perfusion of sweat from patients with CFP could not be due to the amount of sodium brought into the gland duct by means of the infusion procedure as this amount did not differ quantitatively from that used in control experiments with sodium-enriched sweat from normal controls (see Figs. 1-3).

Our data strongly support the hypothesis of Mangos and McSherry [18] that a factor is present in sweat and mixed mouth saliva which might be responsible for the net sodium transport defect. They injected in a retrograde direction sweat and mixed mouth saliva from patients with CFP into the rat parotid and observed a significant increase in sodium concentration at all flow rates of the saliva produced thereafter.

Support for this hypothesis was added by the experiments of Desjeux and Morin [2]. They found a 6-50\% reduction of the sodium transport-linked alanine uptake in the rat gut after incubation with saliva from patients with CFP.

One has to consider that the net rate of sodium reabsorbed is always the result of two opposed components: active transport in the one and passive back diffusion (leak diffusion) in the reverse direction [1, 23]. Interference by the factor with one or the other process is possible. This would mean either diminished rate of active sodium transport from the luminal to the interstitial side of the duct cells, or elevated leak diffusion resulting from increased membrane permeability. None of the results cited $[2,17,18]$ permits a decision of the factor's action on the inner membrane permeability or the sodium pump, and this cannot be done definitively with our results. The increased sodium concentration in sweat after sweat perfusion merely reflects lower net sodium reabsorption in the duct. A comparison of the results obtained after infusion with those after intracutaneous infiltration, however, favors the interaction of the factor with the inner membrane, whereas reduced net rate of active transport would appear to be less probable. The pump for active transport is generally accepted to be localized on the contraluminal side, as ouabain, which partially inhibits this pump, is acting by contraluminal application only $[9,14]$. There was no indication that an ouabain-like effect occurred when sweat-CFP was applied from the contraluminal side in our experiments (Table I). Thus, action of the factor on active sodium transport appears improbable. Following application from the duct, however, a significant increase was observed in sodium concentration (Figs. 1, 2), indicating that the factor was effective from the luminal side. Possibly this was the result of an increase of leak diffusion, and a comparison can be made with strongly charged polycationic macromolecules whose permeability-increasing effect on cell membranes is well established [13, 15, 16]. Mangos and McSherry [18] even demonstrated an increase in the sodium concentration of parotid saliva after perfusion of the duct with these substances.

An increased potassium secretion under the influence of the "factor" might be suggested from the elevated potassium values after infusion with sweat-CFP (Fig. 3). This might well be in accordance with the elevated potassium values of sweat observed in CFP [7]. On the other hand, the amount of potassium infused with the sweat of patients with CFP was higher than that found in the controls, and no quantitative estimation of this difference was done. Although the elevated potassium values provide evidence in favor of a CFP effect, a clear decision cannot be made.

\section{Conclusion}

Summarizing all these data, the following possible outline of the basic defect in sweat performance in CFP can be given. The coil of the sweat gland secretes a normal volume of precursor sweat isotonic to plasma [20]. During passage through the sweat gland duct a significantly lower net amount of sodium is reabsorbed. This was shown first by Slegers [22] and confirmed by Emrich et al. [7]. Here, active transport was probably unaffected as we presume from our results and can be deduced from experiments with aldosterone $[6,8,11,12]$.

Previously published results make it appear unlikely that hypertonicity of the precursor sweat, an increase in sweat rate, or increased reabsorption of water by the sweat duct will explain the high sodium concentration found in sweat of patients with CFP [7, 20].

Our results indicate that probably a factor present in sweat of patients with CFP is responsible for the basic electrolyte defect in the final sweat. Action of this factor on the side of the sodium pump is very unlikely. Presumably it is effective from the luminal face of the gland by interfering with the membrane structures, thus increasing leak diffusion.

\section{References and Notes}

1. Baldamus, C. A., Hierholzer, K., Rumrich, G., Stoll, H., Uhlich, E., UlLRICH, K. J., AND Wiederholt, M.: Natriumtransport in den proximalen Tubuli und den Sammelrohren bei Variation der Natriumkonzentration im umgebenden 
Interstitium. Pflügers Arch. Gesamte Physiol. Menschen Tiere, 310: 354 (1969).

2. Desjeux, J. F., And Morin, C. L.: The effect of saliva and serum of cystic fibrosis on alanine in vitro intestinal transport (Abstract). Meeting of European Society for Pediatric Research, Stockholm, p. 10 (1970).

3. Di Sant'Agnese, P. A., Darling, R. C., Perera, G. A., and SHEA, E.: Abnormal electrolyte composition of sweat in cystic fibrosis of pancreas: Clinical significance and relationship to disease. Pediatrics, 12:549 (1953).

4. Di Sant'Agnese, P. A., and Talamo, R. C.: Pathogenesis and physiopathology of cystic fibrosis of the pancreas. New Engl. J. Med. 277: 1287, 1343, 1399 (1967).

5. Di Sant'Agnese, P. A., Talamo, R. C., Grand, R. J., and Pallavicini, J. C.: Effect of aldosterone on sweat in normal subjects and patients with cystic fibrosis. In: P. A. Di Sant'Agnese, Ed.: Research on Pathogenesis of Cystic Fibrosis of Pancreas, Proceedings of the Third International Conference, Bethesda, p. 189 (1964).

6. Edelman, J. S., Bogdroch, R., and Porter, G. A.: Specific action of aldosterone on RNA synthesis. Trans. Ass. Amer. Physicians, 77: 307 (1964).

7. Emrich, H. M., Stoll, E., Friolet, B., Colombo, J. P., RICHTERICH, R., AND Rossi, E.: Sweat composition in relation to rate of sweating in patients with cystic fibrosis of the pancreas. Pediat. Res., 2: 464 (1968).

8. Emrick, H. M., Stoll, E., ANd Rossi, E.: Aldosteronwirkung auf die Natrium- und Kaliumausscheidung im Schweiss von Mucoviscidosepatienten und Gesunden. Klin. Wochenschr., 48: 966 (1970).

9. Frazier, H. S., and Hammer, E. I.: Efflux of sodium from isolated toad bladder. Amer. J. Physiol., 205: 718 (1963).

10. GerTz, K. H.: Transtubuläre Natriumchloridflüsse und Permeabilität für Nichtelektrolyte im proximalen und distalen Konvolut der Rattenniere. Pflügers Arch. Gesamte Physiol. Menschen Tiere, 276: 336 (1963).

11. Grand, R. J., Di Sant'Agnese, P. A., Talamo, R. C., and Pallavicini, J. C.: The effects of exogenous aldosterone on sweat electrolytes. I. Normal subjects. J. Pediat., 70: 346 (1967).

12. Grand, R. J., Dy Sant'Agnese, P. A., Talamo, R. C., and Pallavicini, J. C.: The effects of exogenous aldosterone on sweat electrolytes. II. Patients with cystic fibrosis of the pancreas. J. Pediat., 70: 357 (1967).

13. Katchalsky, A., Danon, D., Nevo, A., And De Vries, A.: Interactions of basic polyelectrolytes with the red blood cells. Biochim. Biophys. Acta, 33: 120 (1959).
14. Koefoed-Johnsen, V., And Ussing, H. H.: The nature of the frog skin potential. Acta Physiol. Scand., 42: 298 (1958).

15. Kornguth, S. E., Srahmann, M. A., and Anderson, J. W.: Effect of polylysine on the cytology of the Ehrlich ascites tumor cells. Exp. Cell Res., 24: 484 (1961).

16. Mamelak, M., Wissig, S. L., Bogoroch, R., and Edelman, J. S.: Physiological and morphological effects of poly-L-lysine on the toad bladder. Membrane Biol., 1: 144 (1969).

17. Mangos, J. A., AND McSherry, N. R.: Sodium transport: Inhibitory factor in sweat of patients with cystic fibrosis. Science, 158: 135 (1967).

18. Mangos, J. A., AND MCSherry, N. R.: Studies on the mechanism of inhibition of sodium transport in cystic fibrosis of the pancreas. Pediat. Res., 2: 378 (1968).

19. Richterich, R., AND Friolet, B.: The effect of acetazolamide on sweat electrolytes in mucoviscidosis. Metabolism, 12: 1112 (1963).

20. Schulz, I. J., Di Sant'Agnese, P. A., Orloff, J., Froemter, E., AND UlLRICH, K. J.: Micropuncture studies of the sweat formation in cystic fibrosis patients. Fed. Proc., 26: 287 (1967).

21. Schulz, I. J., Ullrich, K. J., Froemter, E., Holzgreve, H., Frick, A., AND Hegel, U.: Mikropunktion und elektrische Potentialmessung an Schweissdrüsen des Menschen. Pflügers Arch. Gesamte Physiol. Menschen Tiere, 284: 360 (1965).

22. SLEGERS, J. F. G.: The mechanism of eccrine sweat gland function in normal subjects and patients with mucoviscidosis. Dermatologica, 127: 242 (1963).

23. UllRich, K. J., Baldamus, C. A., Uhlich, E., AND RUMrich, G.: Einfluss von Calciumionen und antidiuretischem Hormon auf den transtubulären Natriumtransport in der Rattenniere. Pflügers Arch. Gesamte Physiol. Menschen Tiere, 310: 369 (1969).

24. Young, J. A., AND SCHÖGEL, E.: Micropuncture investigation of sodium and potassium excretion in rat submaxillary saliva. Pflügers Arch. Gesamte Physiol. Menschen Tiere, 291: 85 (1966).

25. Fluimucil, Inpharzan.

26. Volpi, Urdorf, Switzerland.

27. Leitz, Wetzlar, Germany.

28. Leitz, Wetzlax, Germany.

29. Informed consent was obtained for all subjects in the study.

30. Supported by Swiss National Fund Grant no. 3.198.69.

31. Requests for reprints should be addressed to: D. Kaiser, Department of Pediatrics, University of Bern, $\mathrm{CH} 3008$ Bern, Switzerland.

32. Accepted for publication July 14, 1970. 